\title{
MALIGNANT TUMOURS IN LABRADOR RETRIEVERS USED FOR NARCOTIC DETECTION
}

Miloš Pelić ${ }^{1}$, Biljana Božić ${ }^{1}$, Marko Pajić ${ }^{1}$, Ivana Vučićević ${ }^{2}$, Milena Samojlovićs ${ }^{3}$, Vladimir Polaček ${ }^{1}$

${ }^{1}$ Scientific Veterinary Institute "Novi Sad",Novi Sad, Serbia

${ }^{2}$ Faculty of Veterinary Medicine,University of Belgrade, Department of Pathology, Belgrade, Serbia ${ }^{3} \mathrm{PhD}$ Student of Faculty of Agriculture, University of Novi Sad, Department of Veterinary Medicine, Novi Sad, Serbia

\section{Abstract}

The two corpses of police dogs, of Labrador retriever breed used for finding narcotics, were sent to the Scientific Veterinary Institute "Novi Sad", and examined post-mortem, in order to determine the cause of death. Post-mortem examination revealed the presence of neoplastic changes in the mandibular region, pulmonary parenchyma and axillary region. The samples of neoplastic changes were sent to the Laboratory of Patohistology within the Faculty of Veterinary Medicine, University of Belgrade, in order to specify the diagnosis. Histopathology examination revealed an adenocarcinoma in lungs and haemangioendothelioma in axillary region. Is there any role of drug sniffing on the occurrence of neoplasia in Labrador retriever breed is still unknown, but it could be an important factor in the development of neoplasia in these dogs.

Key words: lung adenocarcinoma, Haemangioendothelioma, Histopathology, Labrador retriever.

\footnotetext{
${ }^{1}$ Corresponding author: milos.pelic87@gmail.com
} 


\title{
MALIGNI TUMORI KOD LABRADOR RETRIVERA KOJI SE KORISTE ZA PRONALAŽENJE NARKOTIKA
}

\author{
Miloš Pelićc ${ }^{\star}$, Biljana Božić ${ }^{1}$, Marko Pajić ${ }^{1}$, Ivana \\ Vučićević ${ }^{2}$, Milena Samojlović ${ }^{3}$, Vladimir Polaček ${ }^{1}$ \\ ${ }^{1}$ Naučni institut za veterinarstvo "Novi Sad“,Novi Sad, Srbija \\ ${ }^{2}$ Fakultet veterinarske medicine, Univerzitet u Beogradu, \\ Katedra za patološku morfologiju, Beograd, Srbija \\ ${ }^{3}$ Student doktorskih studija Poljoprivrednog fakulteta, Univerzitet u \\ Novom Sadu, Departman za Veterinarsku Medicinu, Novi Sad, Srbija
}

\section{Kratak sadržaj}

Dva leša policijskih službenih pasa, rase Labrador retriver koji se koriste za pronalaženje narkotika, dostavljeni su u Naučni institut za veterinarstvo "Novi Sad", kako bi se na osnovu patomorfološkog pregleda utvrdio uzrok smrti. Tokom obdukcije utvrđeno je prisustvo neoplastičnih promena $\mathrm{u}$ mandibularnoj regiji, plućnom parenhimu i aksilarnoj regiji. Uzorci promenjenog tkiva dostavljeni su na Fakultet veterinarske medicine, Univerziteta u Beogradu, u laboratoriju za patohistologiju kako bi se odredila tačna dijagnoza. Patohistološkim nalazom utvrđeno je prisustvo adenokarcinoma u plućima i hemangioendotelioma u predelu aksilarne regije. Kakvu ulogu može imati udisanje narkotika na pojavu neoplazmi kod Labrador retrivera još uvek nije poznato, ali se pretpostavlja da to može biti jedan od faktora u nastanku neoplastičnih promena kod ovih službenih pasa.

Ključne reči: adenokarcinom pluća, hemangioendoteliom, patohistologija, Labrador retriver.

\section{INTRODUCTION}

Labrador retriever dogs are often used as sniffer dogs - they are trained by a large number of law enforcement agencies and rescue teams worldwide. These dogs are able to detect the scents of illegal drugs, explosives, flammable materials, and other contraband items such as illegal imports of ivory (Oesterhelweg et al., 2008). Drug-sniffing dogs may be exposed to illicit drugs and other toxic agents in the line of duty, most commonly through inhalation and ingestion. Ingestion is the most common route of exposure. They may ingest whole bags of drugs which must be removed surgically or via endoscopy to prevent rupture and massive exposure. Police dogs may be at increased risk 
for malicious poisonings (Gupta R., 2012). Inhalation exposures are generally of lesser magnitude but may result in a more rapid onset of action of the agent (Llera and Volmer, 2006). When compared to the pet population, police dogs had a higher risk of developing neoplasms (Kippens and Grondalen, 1999). This case presentation describes the presence of malignant tumours in two police dogs, Labrador retriever breed trained for finding drugs.

\section{CASE PRESENTATION}

During 2015 and 2016, two corpses of official police dogs used for drug detection were brought to the Scientific Veterinary Institute " Novi Sad " to determine the cause of death. The necropsy was performed at the autopsy hall of the Scientific Veterinary Institute " Novi Sad ". The first dog was a 12-yearsold male Labrador retriever weighing around $40 \mathrm{~kg}$. The second dog was a 15 -years-old male Labrador retriever weighing approximately $50 \mathrm{~kg}$. Both dogs were non-neutered dogs, older than 10 years and in very poor body condition. They were short hair yellow dogs. Both dogs were found dead in police rooms intended for the accommodation of service dogs. There were no data regarding a previous treatment of dogs.

During external post-mortem examination of the first dog, in the area of mandibular region globular formation of hard consistency was observed. This neoplastic change was $2 \times 2 \mathrm{~cm}$ in diameter, while the surrounding tissue was oedematous, haemorrhagic, jelly-like consistency. The left lung was enlarged, and during palpation of the lung parenchyma, neoplastic change $5 \times 3 \mathrm{~cm}$ in diameter was detected (Figure 1-A). This neoplastic change was hard consistency. On cross-section of the left lung, sticky dark red liquid was observed (Figure 1-B). By separating synsarcosis connection of front left limb of second dog, in the area of the axillary region tumour mass was detected (Figure 2-B). This neoplastic change was round shaped, about $10 \mathrm{~cm}$ in diameter, hard consistency, and protruded above the surface (Figure 2-A). On cut section, the structure of this tumour was liver-like, dark red coloured (Figure 2-C). The structure of the affected ribs had been completely destroyed, and this neoplastic change penetrated in the area of the chest cavity (Figure 2-D).

After necropsy and tissue sampling, the samples were sent to the Laboratory for Patohistology, at the Faculty of Veterinary Medicine, University of Belgrade in order to specify the diagnosis. For patohistological analysis, the sample was fixed in $10 \%$ neutral-buffered formalin, embedded in paraffin, and sections of $4 \mu \mathrm{m}$ thickness were cut. These sections were stained with haematoxylin and eosin (H\&E). Histopathologically, a well-differentiated adenocarcinoma 
with squamous metaplasia was diagnosed at the left lung of 12-years-old dog. Microscopically, the neoplastic tissue of lungs showed mix of small basaloid cells and larger differentiated cells that were polygonal, with abundant glassy eosinophilic cytoplasm and prominent atypia of neoplastic cells. Acinar differentiation with formation of lumens was clearly evident, along with squamous differentiation of cells. Histopathological examination of neoplastic change of 15-years-old dog confirmed Haemangioendothelioma of axillary region. Microscopically, neoplastic tissue of axillary region had numerous irregular vascular channels and large areas of haemorrhage. Tumour cells were consisted of pleomorphic endothelial cells, ranging from spindle-shaped to polygonal to ovoid.

\section{DISCUSSION}

Malignant tumours are a common health problem in dogs worldwide. All dog breeds, as well as crossbred dogs may be affected, and it is notable that some purebred dogs appear to be at increased risk of certain types of malignant tumours, suggesting underlying genetic predisposition (Dobson, 2013).

Adenocarcinoma is a malignant tumour originating in the glandular and epithelial tissue (the lining of the internal organs). This type of malignant tumour growth can take place in many parts of the body. It commonly affects older dogs, usually more than six years of age. No particular breed is known to be predisposed and it is more common in male dogs than females. This type of tumours usually has a poor prognosis. The exact cause is still unknown. According to Scanziani et al. (1991) genetic cause is suspected in Belgian shepherds.

Reported to Ogilive et al. (1989) incidence of lung cancers in dogs is markedly lower than in humans, and accounts for approximately $1.2 \%$ of all tumours (Brodey and Craig, 1965; Sato et al, 2005). Pulmonary carcinoma with components of both adenomatous and squamous cells is classified as adenocarcinomas with squamous metaplasia. This type of tumours have been reported in large-scale surveys in dogs, accounting for approximately 13\% of primary lung tumours (Hahn et al., 1996; Griffey et al., 1998; Sato et al., 2005). Metastatic lung cancers are much more common in dogs than primary lung cancers. Most of primary lung tumours are diagnosed in dogs average age of 10 to 12 years.

Haemangiosarcoma (HSA, malignant hemangioendothelioma), a malignant tumour of endothelial cells, occurs most frequently in old dogs, but is less common than haemangioma. Hemangiosarcoma is an aggressive and common cancer in dogs and it has been estimated to represent $7 \%$ of canine malignant tumours (Dobson, 2013). German shepherd dogs are most commonly affected, 
and some other breeds are over-represented. Hemangiosarcoma is a highly malignant tumour arising from blood vessels, probably less common than some of the other mesenchymal malignancies. The most common primary sites for hemangiosarcoma in dogs are visceral organs, notably the spleen and liver; it may also arise in the right atrial appendage. (Dobson, 2013). Metastasis most often occurs to the liver, omentum, mesentery, lungs either hematogenously or through transabdominal transplantation via seeding after tumour rupture. Most affected dogs die from acute internal haemorrhage secondary to rupture of the tumour. Despite surgical and chemotherapeutic management, the median survival time for dogs diagnosed with HSA is little more than 6 months (Hammer et al., 1991; Clifford et al., 2000; Sorenmo et al., 2000; Sabattini and Bettini, 2009). The breed that appears to be predisposed is the German shepherd dog, and other commonly reported breeds include the Golden retriever, Pointer, Boxer, Labrador retriever, English setter, Great dane, Poodle, and Siberian husky (Smith, 2003). German shepherd dog has been reported to has an increased risk with an odds ratio of 4.7, compared to other purebred dogs (Prymac et al., 1985). More recently hemangiosarcoma appears to has become a significant problem in Golden retrievers in North America with an estimated life-time risk of 1 in 5 reported by the Golden Retriever Club of America (Tamburini et al., 2009; Dobson, 2013). The tumour occurs predominantly in older dogs between 8 and 10 years of age; mean age at time of diagnosis is 9 to 12 years (Sharma, 2012). Labrador retriever and Golden retriever dog breeds count for a high ratio of visceral hemangiosarcomas and skin hemangiomas and a slightly lower ratio of nonvisceral hemangiosarcoma. Dogs with hemangiomas are younger than those with hemangiosarcoma. Any type of hemangiosarcoma is rare in young dogs (Schultheiss, 2004).

The epidemiological study performed by Mialot and Lagadic (1990) remarked positive correlation between age of dogs and cats with tumour incidence. The increase in tumour incidence is correlated until the age of 10 years with animal age, in both dogs and cats. Tumour frequency remains high until the age of 12 years in dogs and 13 years in cats, then it gradually reduce, because of the life duration of these species.

There is no evidence which support addiction of dogs trained to detect hard narcotics, or even run the risk of becoming addicted, to the narcotics which they are trained to detect. A sniffer dog during the training for narcotic detection does not come in physical contact with narcotic agents. The only contact the dog has with the narcotic sample is related to sniffing the sample package. Two cases of malignant tumour in dogs that are used for the detection of narcotics are insufficient to examine the relationship between tumour 
occurrences in these working dogs. In the literature there is no enough information about what kind of impact drugs can have on the health of sniffer dogs and the occurrence of tumours in this breed, although many drug-induced diseases are known in human population (Irey, 1976; Challita et al., 2014). It has been confirmed that neoplastic changes were the second leading cause of death or euthanasia in working dogs in the USA (Moore et al., 2001). This findings may suggest a possible role of chronic drug exposing to occurrence of neoplastic changes in sniffing dogs, so the further investigations may determinate the possible correlation.

\section{ACKNOWLEDGEMENTS}

This work was supported by the Ministry of Science and Technological Development of the Republic of Serbia, grants TR 31071.

\section{REFERENCE}

1. Brodey R.S. and Craig P. H.: Primary pulmonary neoplasms in the dog: a review of 29 cases. Journal of the American Veterinary Medical Association, 147,12, 1628-1623, 1965.

2. Challita S., Daher M., Roche N., Alifano M., Revel M.P., \& Rabbat A. Pneumorachis after cocaine sniffing. Respiratory Medicine Case Reports, 12, 10-12, 2014.

3. Clifford C.A., Mackin A.J., and Henry C.J.: Treatment of canine hemangiosarcoma: 2000 and beyond. Journal of Veterinary Internal Medicine, 1, 5, 479-485, 2000.

4. Dobson J.M.: Breed-predispositions to cancer in pedigree dogs. ISRN Veterinary Science Volume 2013 (2013), Article ID 941275, 23, 2013. http:// dx.doi.org/10.1155/2013/941275

5. Griffey S.M., Kraegel S.A., and Madewell B.R.: Rapid detection of K-ras gene mutations in canine lung cancer using single-strand conformational polymorphism analysis. Carcinogenesis, 19, 6, 959-963, 1998.

6. Gupta R.C. (Ed.). Veterinary toxicology: basic and clinical principles. Academic press, 2012.

7. Hahn F.F., Muggenburg B.A., and Griffith W.C.: Primary lung neoplasia in a beagle colony. Veterinary Pathology Online, 33, 6, 633-638, 1996.

8. Hammer A.S., Couto C.G., Filppi J., Getzy D., and Shank K.: Efficacy and toxicity of VAC chemotherapy (vincristine, doxorubicin, and cyclophosphamide) in dogs with hemangiosarcoma. Journal of Veterinary Internal Medicine, 5, 3, 160-166, 1991. 
9. Irey N.S. Teaching monograph. Tissue reactions to drugs. The American Journal of Pathology, 82, 3, 613, 1976.

10. Kippens H., Grondalen J.: Health status of police patrol dogs and selected German Shepherds. Norsk Veterinaertisskrift, 111, 3, 145-150, 1999.

11. Llera R.M and Volmer P.A : Toxicologic hazards for police dogs involved in drug detection, Journal of the American Veterinary Medical Association, 228, 7, 1028-1032, 2006.

12. Mialot M., Marie Lagadic.: Epidemiologie descriptive des tumeurs du Chien et du Chat. Recueil de Medecine Veterinaire, 166, 11, 937-94, 1990.

13. Moore G.E., Burkman K.D., Carter M.N. Causes of death or reasons for euthanasia in military working dogs: 927 cases (1993-1996). Journal of the American Veterinary Medical Association, 219, 209-214, 2001.

14. Oesterhelweg L., Kröber S., Rottmann K., Willhöft J., Braun C., Thies N., ... \& Gehl, A.: Cadaver dogs-a study on detection of contaminated carpet squares. Forensic science international, 174, 1, 35-39, 2008.

15. Ogilvie G.K., Haschek W.M., Withrow S.J., Richardson R.C., Harvey H.J., Henderson R.A., ... and McCaw D.: Classification of primary lung tumors in dogs: 210 cases (1975-1985). Journal of the American Veterinary Medical Association, 195, 1, 106-108, 1989.

16. Prymak C.A.R.O.L.I.N.E., McKee, L.J., Goldschmidt M.H., and Glickman L.T.: Epidemiologic, clinical, pathologic, and prognostic characteristics of splenic hemangiosarcoma and splenic hematoma in dogs: 217 cases (1985). Journal of the American Veterinary Medical Association, 193, 6, 706-712, 1988.

17. Sabattini S. and Bettini G.: An immunohistochemical analysis of canine haemangioma and haemangiosarcoma. Journal of Comparative Pathology, 140, 2, 158-168, 2009.

18. Sato T., Ito J., Shibuya H., Asano K., Watari T.: Pulmonary Adenosquamous Carcinoma in a Dog. Journal of Veterinary Medicine, 510-513, 2005.

19. Scanziani E., Giusti A.M., Gualtieri M., and Fonda D.: Gastric carcinoma in the Belgian shepherd dog. Journal of Small Animal Practice, 32, 9, 465469, 1991.

20. Schultheiss P.C.: A retrospective study of visceral and nonvisceral hemangiosarcoma and hemangiomas in domestic animals. Journal of Veterinary Diagnostic Investigation, 16, 6, 522-526, 2004.

21. Sharma D.: Hemangiosarcoma in a geriatric Labrador retriever. The Canadian Veterinary Journal, 53, 8, 889, 2012.

22. Smith A.N.: Hemangiosarcoma in dogs and cats. Veterinary Clinics of North America: Small Animal Practice, 33, 3, 533-552, 2003. 
23. Sorenmo K., Duda L., Barber L., Cronin K., Sammarco C., Usborne, A., ... and Shofer F.: Canine hemangiosarcoma treated with standard chemotherapy and minocycline. Journal of Veterinary Internal Medicine, 14, 4, 395-398, 2000.

24. Tamburini B.A., Trapp S., Phang T.L., Schappa J.T., Hunter L.E., and Modiano J.F.: Gene expression profiles of sporadic canine hemangiosarcoma are uniquely associated with breed. PLoS One, 4, 5, e5549, 2009.
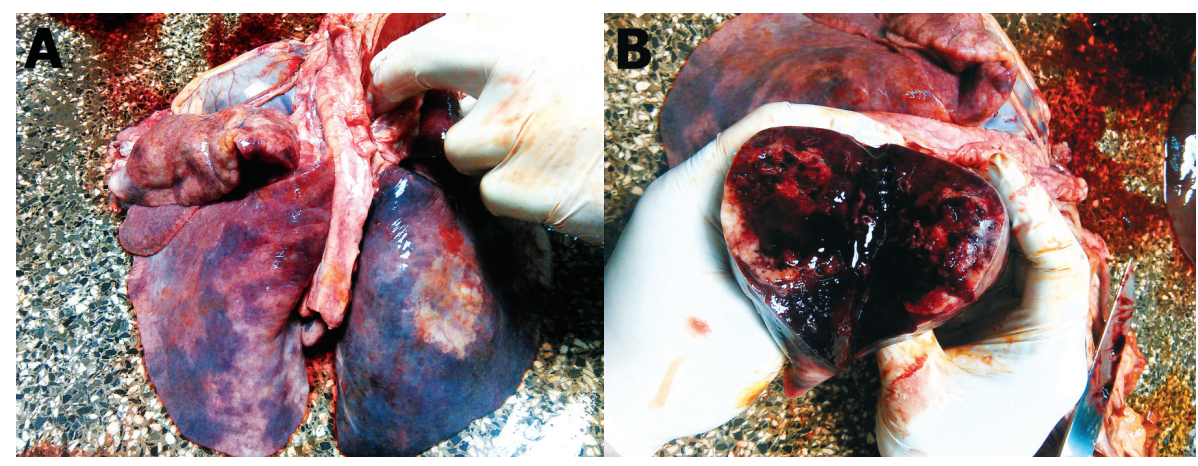

Figure 1. Post-mortem examination: Gross appearance (A) and cut of surface of the tumour (B). 


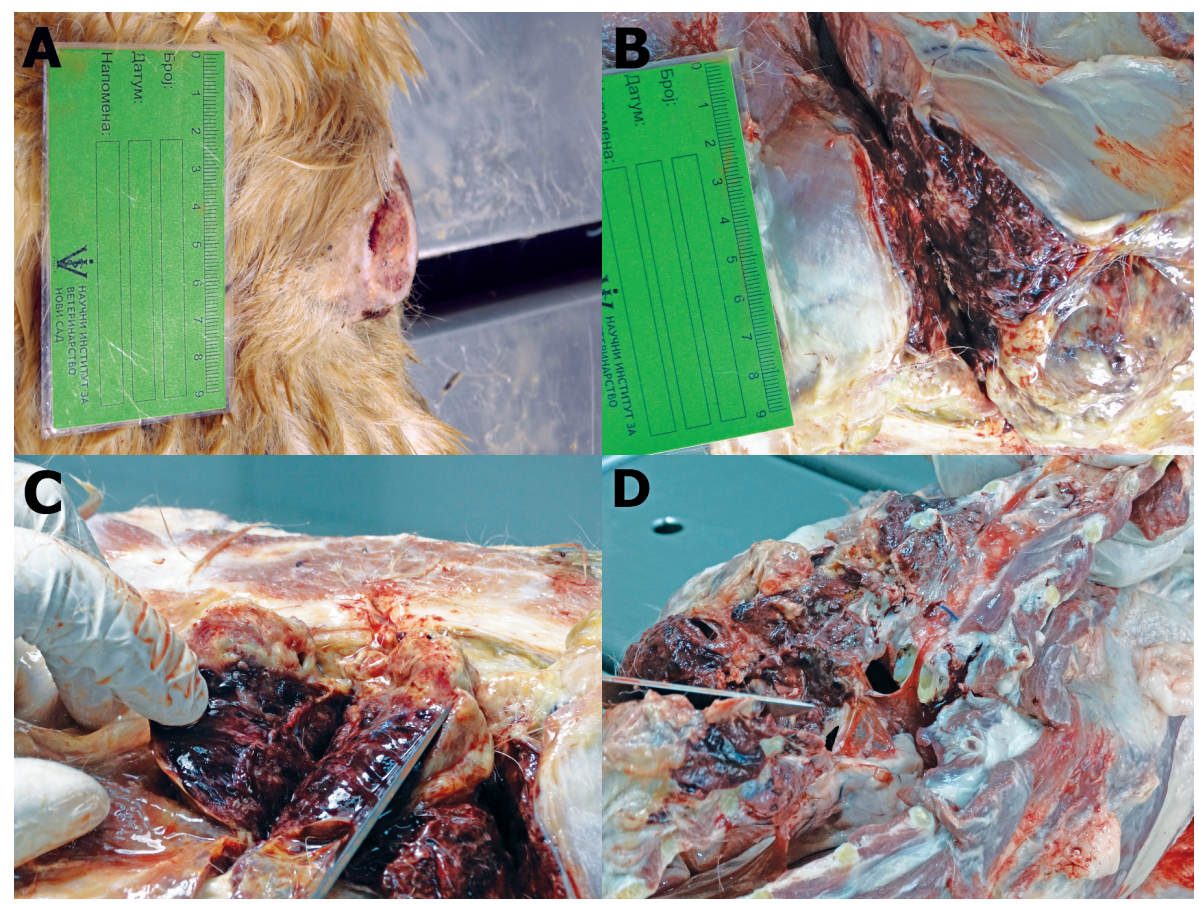

Figure 2. Post-mortem examination: Clinical aspect (A), gross appearance (B), cut of surface of the tumour $(C)$ and structure of the affected ribs (D).

Primljeno: 20.09.2016.

Odobreno: 10.10.2016. 